anales de psicología / annals of psychology

2019, vol. $35, \mathrm{n}^{\circ} 3$ (october), 444-452

http://dx.doi.org/10.6018/analesps.35.3.323681
(C) Copyright 2019: Editum. Servicio de Publicaciones de la Universidad de Murcia. Murcia (Spain) ISSN print edition: 0212-9728. ISSN on line edition (http://revistas.um.es/analesps): 1695-2294.

On line edition License Creative Commons 4.0: BY-NC-ND

\title{
Examining the Factors Contributing to Adolescents' Online Game Addiction ${ }^{1}$
}

\author{
Seyhan Bekir², and Eyüp Çelik ${ }^{3 *}$ \\ 2 Uludağ University, Institute of Educational Sciences, Bursa (Turkey) \\ 3 Sakarya University, Faculty of Educational Sciences, Sakarya (Turkey)
}

\begin{abstract}
Título: Examen de los factores que contribuyen a la adicción al juego on line en adolescentes.

Resumen: En este estudio, el objetivo fue examinar el nivel de adicción a los juegos on line entre los estudiantes de secundaria en términos de necesidades psicológicas básicas y búsqueda de sensaciones. El grupo de estudio consistió en 214 estudiantes de secundaria, 150 de los cuales eran hombres y 64 mujeres. Los datos del estudio se recolectaron utilizando la Escala de Adicción a los Juegos en Línea, la Escala de Necesidades Psicológicas Básicas y la Escala de Búsqueda de Sensaciones. La variable dependiente de la investigación es la adicción a los juegos on line, mientras que las variables independientes son la búsqueda de emoción, las necesidades psicológicas básicas, el género, el tipo de juego on linr que el individuo aprende y el tipo de juego on line. El análisis de regresión múltiple se utilizó para determinar si las variables independientes predijeron la variable dependiente. De acuerdo con el resultado del análisis de correlación, se ha encontrado que existe una relación positiva y significativa entre la adicción al juego on line y la búsqueda de sensaciones y las necesidades psicológicas básicas.

Palabras clave: adicción a juegos on line; necesidades psicológicas básicas;
\end{abstract} búsqueda de sensaciones; adolescente.

\section{Introduction}

Adolescence period is generally reported to start around the age of ten and end in early twenties. Adolescents are also reported to undergo mood swings due to the hormonal and physical changes and emotional fluctuations they experience, and accordingly they encounter difficulties in articulating their mood in a logical way (Steinberg, 2007). Such failure in controlling emotions is mainly attributed to the late development of prefrontal cortex as compared to amygdala. Prefrontal cortex is responsible from functions such as reasoning, decision making and self-control, and its development continues throughout adolescence (Luciana, 2010), whereas the development of amygdala, responsible from emotions such as anger, is completed earlier, thus preventing adolescents from controlling their emotions (Casey, Duhoux, \& Cohen, 2010). Moreover, results of recent researches on the subject (Albert \& Steinberg, 2011; Chein, Albert, O’Brien, Uckert, \& Steinberg, 2011) show that, adolescents' tendency for reward-seeking and taking risks is higher than that of adults. In this context, increased levels of reward-seeking and risk-taking behaviors can increase online game addiction for adolescents.

* Correspondence address [Dirección para correspondencia]

Eyüp Çelik. Sakarya University, Faculty of Educational Sciences, Sakarya (Turquía). E-mail: eyupcelik@,sakarya.edu.tr

(Article received: 05-03-2018; revised: 11-06-2018; accepted: 12-6-2018)

1 Part of this study was presented an oral presentation at the 1 th Higher Education Research and Practices Congress.
Abstract: In this study, it was aimed to examine the level of online game addiction among adolescents in terms of basic psychological needs, sensation seeking and some variables. The study group of the study consisted of 214 high school students, 150 of whom were male and 64 female. Data from the study were collected using the Online Game Addiction Scale, the Basic Psychological Needs Scale, and the Sensation Seeking Scale. The dependent variable of the research was the online game addiction, while the independent variables were the search for excitement and basic psychological needs. Multiple regression analysis was used to determine whether the independent variables predicted the dependent variable. According to the result of correlation analysis, it was found that there was a positive and significant relationship between online gaming addiction and the sensation seeking and basic psychological needs.

Key words: online game addiction; basic psychological needs; sensation seeking; adolescence.

Individuals' tendency to develop online game addiction in adolescence period can also be attributed to sensation seeking and nonfulfillment of psychological needs. Nonfulfillment of such needs through positive experiences may have adverse effects on adolescents' mental health and in return adolescents may tend towards online games through choosing the avoidance mode (Farrell, Reiss, \& Shaw, 2014) among the maladaptive coping styles introduced in Young's schema theory.

The first electronic game was designed by computer programmer Steve Russell et al. in Massachusetts Institute of Technology (MIT) in 1962. The name of this game was announced as Spacewar. The release of this game throughout USA (Unites States of America), was followed by release of more complicated computers from numerous companies due to the game factor. The affordable price of such computers $(600 \$)$ resulted in a sales boom and inconceivable amounts of profit by these companies. In return for this game attack of USA, the Tetris game was designed in Russia by Alexey Pazhitnov, which triggered an incredible development in the world of games (Yılmaz \& Çağıltay, 2005). It can be inferred from these facts that, digital games in fact played an important role in development of computers. This is also verified by the simultaneous development of game graphics with hardware features of computers. According to Peltoniemi (2002), online game addiction is a sub-branch of internet addiction. The main feature that distinguishes these games from other classical video games is that they are being played online and therefore enable interactive environments (Choi \& Kim, 2004 cited in Madran and Çakılc1, 2014). These interactive environments allow humans to experiment with 
parts of their personality and new identities (Young, 2009). Additionally, Madran and Çakıcı (2014) suggest that this type of addiction can be explained on the basis of internet computer addiction.

Studies reported that, men score higher than women on measures of sensation-seeking (e.g. Cross, Cyrenne, \& Brown, 2013; Rahmani \& Lavasani, 2012) and online games (e.g. Ko, Yen, Chen, Chen, \& Yen, 2005; McInroy ve Mishna, 2017). Need for competence that one of the psychological need (Arslanoğlu, Tekin, Arslanoğlu, \& Özmutlu, 2010) level differ according to gender. On the other hand, Yiğit (2012) found that psychological needs didn't differ according to gender.

In literature studies a positive relationship was found between game addiction and narcissism (Kim, Namkoong, Ku, \& Kim, 2008), agression (Kim et al., 2008; Mehroof \& Griffiths, 2010), gambling addiction and sensation seeking (Mehroof \& Griffiths, 2010); and a negative relationship was found between game addiction and self-control (Kim et al., 2008). Ko et al. (2005) reported that, online games are played by males at higher rates and that individuals with lower levels of self-esteem and lower satisfaction with their daily lives exhibit higher levels of addiction. Another study on adolescents indicates that, there is a significantly high relationship with problematic internet usage and online game addiction (Van Rooij, Schoenmakers, Van de Eijnden, \& Van de Mheen, 2010). No study was encountered on relationship between sensation seeking and online gaming in Turkey, however, studies on this subject are available in the international literature (Chiu, Lee, \& Huang, 2004; Lemmens, Valkenburg, \& Peter, 2009; Mehroof \& Griffiths, 2010). As also indicated by numerous studies on internet usage (Çetin \& Ceyhan, 2015; Lin \& Tsai, 2002; Rahmani \& Lavasani, 2011a; Rahmani \& Lavasani, 2011b; Van Rooij et al., 2010), substance addiction (Ersche, Turton, Pradhan, Bullmore, \& Robbins, 2010; Kosten, Ball, \& Rounsaville, 1994), gambling addiction (Blaszczynski, Wilson, \& McConaghy, 1986; Coventry \& Brown, 1993), and online gaming addiction (Chiu, Lee, \& Huang, 2004; Lemmens, Valkenburg, \& Peter, 2009; Mehroof \& Griffiths, 2010) among adolescents in national and international literature, an important indicator of online gambling addiction can be regarded as sensation seeking.

Sensation seeking is a characteristic behavior of adolescence. Adolescents go after new opportunities for new experiences and risky behaviors. Although such behaviors support the development of adolescent as a free individual, they also leave them vulnerable against dangerous situations (Kelley, Schochet, \& Landry, 2004). Reportedly, sensation seeking individuals are more likely to attend thrilling activities such as paragliding, bungee-jumping, mountain climbing and watching horror movies (Stephenson \& Southwell, 2006). In general, research results show that, a relationship exists between depression (Carton, Jouvent, \& Widlöcher, 1992), risktaking (Rolison \& Scherman, 2003), anti-sociality (Çelik, 2015), problematic internet usage (Çetin \& Ceyhan, 2014) and online gaming addiction (Mehroof \& Griffiths, 2010). Also, a significant relationship was found between sensation seeking and hedonism, calculated risk and irresponsible behaviors by Karaman (2013). As indicated by the abovementioned research results, adolescents may develop unrecoverable negative behaviors such as online game addiction, which is further triggered by sensation seeking behaviors of adolescence, as a means to feel good or avoid the negative effects of the problems they undergo in their daily lives.

Adolescents may tend to play online games to fulfill their unsatisfied psychological needs as well. Yarkin (2013) suggests that, psychological needs are innate requirements, though they may have serious impacts on individual's relationship with his/her environment. According to another description, psychological needs have been studied by numerous theoreticians as they are fundamental identifiers for human behaviors (for instance Deci and Ryan, 2000). In the related literature, no study was encountered on the relationship between psychological needs and online game addiction. However, studies on the relationship between psychological needs and submissiveness (Hamurcu \& Sargin, 2011), exposure to cyber bullying (Dilmaç, 2009), internet addiction (Balci \& Ayhan, 2007; Canoğulları, 2014; Kaygusuz, 2013) are available. A positive relationship between submissiveness and the need for success, autonomy and dominance among pshycological needs and a negative relationship between the need for relationship and submissiveness were found by Hamurcu and Sargin (2011) in a study on high school students. According to Dilmaç (2009), the need for perseverance, among psychological needs, is closely related with exposure to cyber-bullying.

The present research focuses on depiction of the variables closely associated with game addiction, which is considered to have various adverse effects on the mental health and development of adolescents. The increasing number of game players in Turkey and uncontrolled sales of video and computer games may lead to the emergence of an unconscious adolescent population. Although games may support some of the attributes of players, the large share of time devoted to games by adolescents is likely to impair their health and mental development (e.g. some of the games may increase the tendency towards violence among adolescents). Excessive game playing may even result with deaths. This is also supported by TV news and other broadcasts regarding the death of several people related with excessive game playing and consequently developing health issues. In this context, adolescents may be exposed to several threats, unless awareness is raised in the society on functional use of games. Increased levels of reward-seeking and risk taking tendencies may arise in adolescence as a result of sensation seeking tendencies. Individuals may tend towards online games as a result of risk-taking and reward-seeking behaviors; as they can earn high amounts of money with some of the online games. Despite such perils of online game addiction, a limited number of researches were found on the subject. In this regard, this study aims to investigate the following hypotheses: 
H1. Online gaming addiction level related to sensation seeking and psychological needs level.

H2. Sensation seeking and psychological needs predict online gaming addiction

H3. Online game addiction level varies according to some demographic variables (gender, type of the game played, who introduced the game).

H4. Sensation seeking and psychological needs levels vary according to gender.

\section{Method}

The research was carried out using relational screening model among quantitative research models. In their research, Christensen et al. (2015) determined the level of relationship between two variables via relational screening model, by which the researcher is allowed to decide whether there is a correlation between the variables through measuring them in their natural state (Christensen, Johnson, \& Turner, 2015).

\section{Participants}

The study group consists of high school students from the districts of Sakarya, İzmir, İstanbul and Muğla that are acquainted with or addicted to online games. Criterion sampling method among non-random sampling methods was used during the research. In this regard, research data were gathered from the high school students that play online games. 150 male and 64 female participants (214 in total) were involved in the research. 143 of the participants are Anatolian high school students, 7 are science high school students, 56 are vocational school students, and 8 are teacher high school students. 51 of the participants are $9^{\text {th }}$ grade, 35 are $10^{\text {th }}$ grade, 83 are $11^{\text {th }}$ grade and 45 are $12^{\text {th }}$ grade students (age range: 14-17). Also, research data were collected from individuals that consented to take part in the research. The sample consist of the individuals who play online games and the percentage is distributed as following: League of Legends $30.4 \%$, Counter Strike 15\%, Online Facebook Games 25.2\%, and other online games $29.4 \% .40 \%$ of Male students and $7.8 \%$ of female students are playing League of Legends the other $20.7 \%$ of male students and $1.6 \%$ of female students are playing Counter Strike GO and $10 \%$ of male students and $60.9 \%$ of females students are playing Facebook Online Games 29.3\% of male students and $29.3 \%$ of male and $29.7 \%$ of female students are playing other online games. The means of the participants' online game addiction are 62.39 for male and 55.22 for female.

\section{Data Collection Tools}

Online Game Addiction Scale (OGAS). The scale was developed by Kaya (2013), and consists of 21 items and 3 subscales (troubles, success and economic profit). Reliability of the scale was examined by Exploratory Factor Analysis (EFA), and its reliability was investigated with Cronbach's Alpha, SpearmanBrown analyses and test-retest method. The last EFA analysis of the scale in the development stage shows that it has a 3 -factor structure that represents $58.55 \%$ of total variance. The lowest factor load for the items of the scale is .606 , and the highest fac- tor load is .876. In the reliability analysis of OGAS, Cronbach's Alpha coefficient is .91 for overall scale, .90 for trouble subscale, .88 for success subscale and .83 for economic profit scale. Spearman-Brown reliability coefficient was found as .94 for overall scale, .91 for trouble subscale, .88 for success subscale and .88 for economic profit subscale. Test-retest reliability coefficient was found as .94 for overall scale, .85 for trouble subscale, .73 for success subscale and .83 for economic profit subscale. Online game addiction scale is a likert- 5 tpe scale $(5=a b-$ solutely agree, $4=$ agree, $3=$ indecisive, $2=$ disagree, $1=$ absolutely disagree). No reverse-coded item was included in the scale from which overall score and subscale scores are obtained.

Basic Psychological Needs Scale (BPNS). The scale was developed by Deci and Ryan (2000) and adapted by Kesici, Üre, Bozgeyikli, and Sünbül (2003). The likert-5 type scale was intended for determination of basic psychological needs and it consists of 21 items and 3 subscales. Its subscales are the needs for competence, autonomy and relatedness. 6-30 points can be obtained from the competence items (items no 3, 5, 10, 13, 15, 19), 7-35 points can be obtained from autonomy items (items no $1,4,8,11,14,17,20)$, and $8-40$ points can be obtained from relatedness items (items no 2, 6, 7, 9, 12, 16, 18, 21). Spearman Brown Rank-Order Correlation Coefficient was calculated between BPNS and Edward Personal Preference Schedule which was adapted by Kuzgun (1988). The correlation between Edward Preference Schedule's (EPS) achievement subscale and BPNS's competence subscale was found as .39, the correlation between EPS's autonomy subscale and BPNS's autonomy subscale was found as .58, and the correlation between EPS's affiliation subscale and BPNS's relatedness subscale was found as .36. Internal consistency coefficient was found as .76 for overall BPNS scale, .61 for competence subscale, .73 for autonomy subscale and .73 for relatedness subscale.

Brief Sensation Seeking Scale (BSSS). The scale was developed by Stephenson, Hoyle, Palmgreen and Slater (2003), and adapted to Turkish by Çelik (2015). Exploratory Factor Analysis (EFA) was applied to evaluate the structural validity of the scale and Turkish version was found to have a single-factor-structure as its original. According to EFA results, the factor load of the scale's Turkish version varies between .74 and .84. Internal consistency coefficient of the Turkish version was found as .81. The scale consists of 4 items and it is in likert- 4 form. The scale yields an overall score. The lowest and the highest possible scores are 4 and 16, and the scale has no reverse coded item.

\section{Data Analysis}

In line with the hypotheses of the study, research data was evaluated using Pearson correlation and multiple regression analysis, t-test and one-way analysis of variance. The relationships between the variables were determined using Pearson correlation analysis. After the Pearson correlation analysis, it was evaluated whether the independent variables (those associated with the dependent variable) significantly predict the dependent variable, by use of regression analysis. It was also evaluated whether the dependent variable varies depending on demo- 
graphic variables using t-test, one-way analysis of variance, and Welch's test. In this context, t test was used to evaluate whether that online game addiction, sensation seeking, and psychological needs level differs according to the gender. One-way analysis of variance was applied to determine whether the online game addiction levels of high school students significantly varied on the basis of the type of the game being played and who introduced the game. During this analysis, one-way analysis of variance was used in the case of homogeneous variances, and Welch's test was applied in the case of non-homogeneous variances. Levene statistics was applied to detect the homogeneity status of variances. Scheffe's test was applied in cases where the results of one-way analysis of variance were found significant to determine which groups exhibit the difference, and Tamhane's T2 test was applied in cases where Welch's test was used for nonhomogeneous variances.

\section{Findings}

The correlations between variables were examined using Pearson correlation analysis and the obtained results are given in Table 1.

Table 1. Correlation Analysis Results.

\begin{tabular}{|c|c|c|c|c|c|c|c|}
\hline Variables & 1 & 2 & 3 & 4 & 5 & 7 & 8 \\
\hline Online Game Addiction & 1 & & & & & & \\
\hline Sensation Seeking & $.25^{* *}$ & 1 & & & & & \\
\hline The Need for Autonomy & $.81 * *$ & $.22^{* *}$ & 1 & & & & \\
\hline The Need for Competence & $.51 * *$ & $.14^{*}$ & $.26^{* *}$ & 1 & & & \\
\hline The Need for Relatedness & $.85^{* *}$ & $.19 * *$ & $.62^{* *}$ & $.58^{* *}$ & 1 & & \\
\hline Grade Level & .09 & .04 & $.13^{*}$ & -.05 & .03 & 1 & \\
\hline Number of Siblings & -.08 & .07 & .05 & -.03 & $-.06^{*}$ & $-.22^{* *}$ & 1 \\
\hline$\overline{\bar{x}}$ & 60.24 & 10.67 & 20.89 & 16.37 & 21.07 & 10.57 & 2.51 \\
\hline$S D$ & 15.52 & 3.36 & 4.80 & 3.01 & 5.13 & 1.07 & 1.56 \\
\hline
\end{tabular}

A positive significant correlation between online game addiction and sensation seeking $(r=.25)$, autonomy $(r=.25)$, competence $(r=.51)$ and relatedness $(r=.85)$ was shown in Table 1. On the other hand, no significant Pearson correlation coefficient was found between the student's grade level, number of siblings and online game addiction. In light of this finding, it was investigated whether online game addiction was statistically significantly predicted by sensation seeking and psychological needs (need for autonomy, competence and relatedness) using multiple regression analysis. Before regression analysis, research data were evaluated in terms of premises of data set regression analysis and the obtained results were presented in Table 2 and
Figure 1 . The suitability of data for regression analysis was evaluated using Mahalanobis distance values, kurtosis, skewness values and normal distribution graph. In this respect, firstly Mahalanobis distance values were detected to determine whether there were multivariate extremes in the data set, these values were then evaluated on the basis of $p<.001$ significance level, and accordingly it was determined that there was no data that impairs the premises of "normality" and "linearity" in the dataset. Afterwards, indicators of normal distribution (kurtosis, skewness and normal distribution graph) were analyzed to examine the suitability of dataset for regression analysis.

Table 2. Results of Regression Analysis Premises.

\begin{tabular}{lcccc}
\hline Variables & Skewness & Kurtosis & VIF & CI \\
\hline Online Game Addiction & .23 & -.64 & & 1.00 \\
Sensation Seeking & -.29 & -.69 & 1.06 & 8.14 \\
Need for Autonomy & .57 & .05 & 1.68 & 11.97 \\
Need for Competence & .05 & -.03 & 1.54 & 14.16 \\
Need for Relatedness & .54 & .30 & 2.32 & 21.37 \\
\hline
\end{tabular}

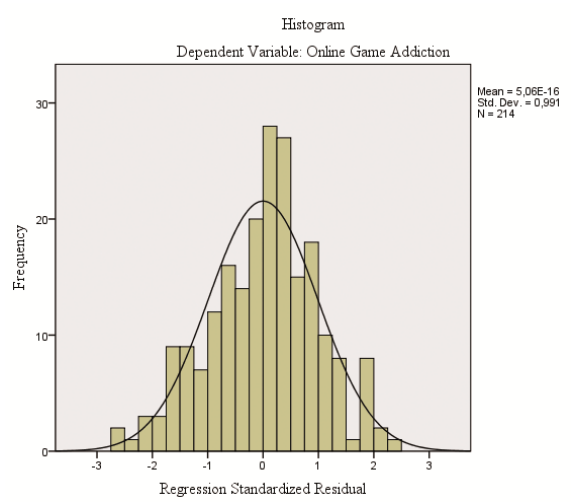

Figure 1. Normal Distribution Curve.
As shown in Table 3, sensation seeking $(\beta=.04)$ did not predict game addiction at a statistically significant level. On the other hand the needs for autonomy $(\beta=.47)$, competence $(\beta=$ .10) and relatedness $(\beta=.50)$ predicts online game addiction as indicated in the table. It can be inferred in light of this finding that, the regression model which involves sensation seeking and psychological needs predicts $86 \%$ of online game addiction. According to the correlation analysis result in Table 1 , sensation seeking $(r=.25)$ did not make a significant contribution to the regression model presented in Table 3 , although it was correlated with online game addiction. The bivariate correlation between sensation seeking and online game addiction is reliably non-zero, yet it can not predict online game addiction in the re- 
gression model, which can be ascribed to the fact that, psychological needs mediates the correlation between sensation seeking and online game addiction, or one or more of the psychological needs repeats the sensation seeking variable. As indicated by the semi-partial correlation values of the predictor variables that predicted online game addiction in Table 3, the need for auton- omy accounts for $13.32 \%$, the need for competence accounts for $0.06 \%$, and the need for relatedness accounts for $12.67 \%$ of online game addiction. Finally, 59.71\% of online game addiction was explained by overlapping autonomy, competence and relatedness variables in the regression model applied to determine the variables that predict online game addiction.

Table 3. Results of Regression Analysis.

\begin{tabular}{|c|c|c|c|c|c|c|c|c|}
\hline \multirow{2}{*}{ Dependent variable } & \multirow{2}{*}{ Predictor Variable } & \multirow{2}{*}{$B$} & \multirow{2}{*}{ Std. Error } & \multirow{2}{*}{$\beta$} & \multirow{2}{*}{$t$} & \multirow{2}{*}{$p$} & \multicolumn{2}{|c|}{ Correlation } \\
\hline & & & & & & & Partial & Semi-partial \\
\hline \multirow{5}{*}{ Online Game Addiction } & Sabit & -13.37 & 2.61 & & -5.11 & .000 & & \\
\hline & Sensation Seeking & .17 & .12 & .04 & 1.39 & .17 & .096 & .035 \\
\hline & Need for Autonomy & 1.53 & .11 & .47 & 14.39 & .000 & .706 & .365 \\
\hline & Need for Competence & .50 & .16 & .10 & 3.09 & .002 & .209 & .078 \\
\hline & Need for Relatedness & 1.50 & .12 & .50 & 12.86 & .000 & .665 & .356 \\
\hline
\end{tabular}

$F(4,209)=336.255, p<.0001$

$\mathrm{R}=.930 ; \mathrm{R}^{2}=.863$

\section{Gender-based Findings}

In the research, t-test was applied to determine whether the online game game addiction, sensation seeking, the need for relatedness, need for autonomy, and need for competence levels of high school students significantly varied depending on their gender. The results were presented in Table 4. As shown in the table, online game addiction, need for relatedness, and need for autonomy significantly varied in a gender-based evaluation. Male participants were found to have significantly higher average online game addiction (Male $\overline{\boldsymbol{x}}=62.39, S S=15.74$; female $\overline{\boldsymbol{x}}=$ 55.22, $S S=15.75$ ), need for relatedness (Male $\bar{x}=21.71, S S=$ 5.07; female $\bar{x}=19.59$, SS= 4.98), and need for autonomy (Male $\overline{\boldsymbol{x}}=21.51, S S=5.18$; female $\overline{\boldsymbol{x}}=19.45, S S=3.39$ ) scores as compared to female participants.

Table 4. The Results of T-test Applied to Make a Gender-based Evaluation of Online Game.

\begin{tabular}{|c|c|c|c|c|c|c|c|c|c|}
\hline & \multicolumn{2}{|c|}{ Levene'Test } & \multicolumn{7}{|c|}{ T-Test } \\
\hline & \multirow[b]{2}{*}{$F$} & \multirow[b]{2}{*}{$p$} & \multirow[b]{2}{*}{$t$} & \multirow[b]{2}{*}{$\mathrm{df}$} & \multirow[b]{2}{*}{$p$} & \multirow[b]{2}{*}{ Mean Difference } & \multirow{2}{*}{$\begin{array}{l}\text { Std. Error } \\
\text { Difference }\end{array}$} & \multicolumn{2}{|c|}{ 95\% Confidence Interval } \\
\hline & & & & & & & & Low & High \\
\hline Online Game Addiction & 2.226 & .137 & -3.158 & 212 & .002 & -7.16792 & 2.27007 & -11.6427 & -2.6931 \\
\hline Sensation Seeking & .954 & .330 & 1.334 & 212 & .184 & .66729 & .50037 & -.31905 & 1.65364 \\
\hline Need for Relatedness & 1.047 & .307 & -2.812 & 212 & .005 & -2.11958 & .75382 & -3.60552 & -.63365 \\
\hline Need for Autonomy & 13.339 & .000 & -2.914 & 212 & .004 & -2.05354 & .70474 & -3.44274 & -.66435 \\
\hline Need for Competence & .054 & .817 & -.752 & 212 & .453 & -.33938 & .45132 & -1.22903 & .55028 \\
\hline
\end{tabular}

\section{Findings Related to the Types of Games}

In the research, Levene test was applied to determine whether the online game addiction levels of high school students significantly varied on the basis of the type of the game being played, by examining the score variances in terms of homogeneity. After the analysis, the variances were found to be non-homogeneous, therefore the results of Welch's test, which was an alternative to $[F(3,210)=4.734, p=.003]$ oneway analysis of variance, were taken into consideration. The results of this test were found to be significant [Welch's Test: $F(3,97)=10.44, p=.000]$. Tamhane's T2 test was used to determine which groups caused the significant difference between the groups as to online game addiction, as this test does not take into account the homogeneity of variances, and the related results were given in Table 6. Also the findings for the online game addiction levels of students on the basis of game types were shown in Figure 2.

Table 5. Descriptive Statistical Results.

\begin{tabular}{|c|c|c|c|c|c|c|c|}
\hline \multirow[b]{2}{*}{ Game Type } & \multirow[b]{2}{*}{$N$} & \multirow[b]{2}{*}{$\bar{x}$} & \multirow[b]{2}{*}{ Std. Dev } & \multicolumn{2}{|c|}{$95 \%$ Confidence Interval } & \multirow[b]{2}{*}{ Lowest Score } & \multirow[b]{2}{*}{ Highest score } \\
\hline & & & & Lower limit & Upper limit & & \\
\hline League of Legends & 65 & 67.508 & 15.714 & 63.614 & 71.402 & 35.00 & 97.00 \\
\hline Counter Strike GO & 32 & 60.938 & 18.663 & 54.209 & 67.666 & 27.00 & 89.00 \\
\hline Facebook Games & 54 & 53.130 & 12.311 & 49.770 & 56.490 & 33.00 & 81.00 \\
\hline Other & 63 & 58.492 & 12.894 & 55.245 & 61.739 & 30.00 & 90.00 \\
\hline Total & 214 & 60.243 & 15.521 & 58.152 & 62.334 & 27.00 & 97.00 \\
\hline
\end{tabular}

As indicated in Tables 5 and 6, online game addiction significantly varies depending on the type of the games played by stu- dents. A statistically significant difference was detected among the mean scores of League of Legends players $(\overline{\boldsymbol{x}}=67.51)$, fa- 
cebook game players $(\overline{\boldsymbol{x}}=53.13)$, and players of other games $(\overline{\boldsymbol{x}}$ $=58.49)$. No significant difference was found for other two paired comparisons. Also, as shown in Table 5 and Figure 2, League of Legends players display higher online game addcition levels compared to the players of other games.

\section{Findings as to Who Introduced the Game}

In the study, homogeneity of score variances was examined with Levene test to determine whether the online game addiction levels of high school students significantly varied depending

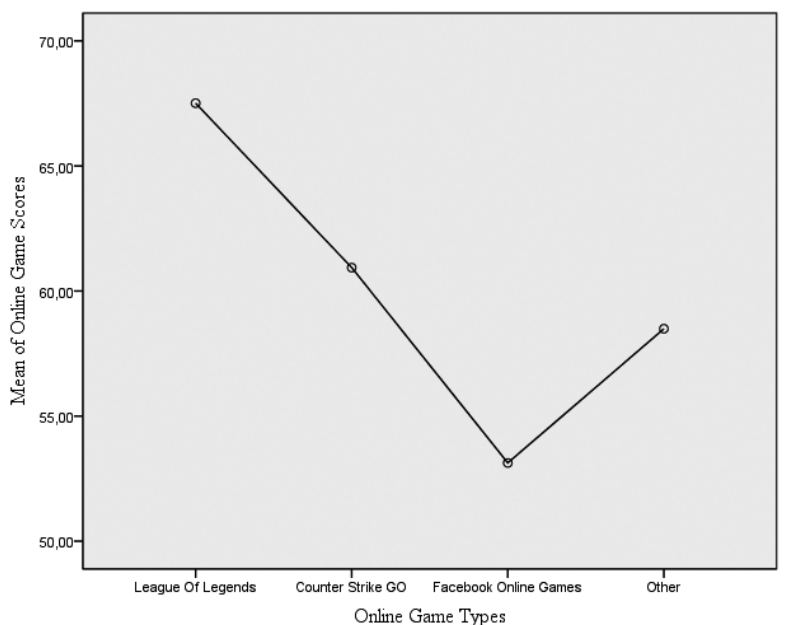

Figure 2. Online Game Addiction Levels of High School Students Depending on the Type of Game. on who introduced the game to the player (family, friend, selftaught). After the analysis, homogeneity of variances were verified and accordingly $[F(2,211)=1.26, p=.285]$ one-way analysis of variance was applied, which yielded significant results $[F$ $(2,211)=3.953, p=.021]$. Descriptive statistics results were given in Table 7 and the findings related to one-way analysis of variance were given in Table 7 . Scheffe's test was used to determine which groups caused this significant difference regarding online game addiction, and the related results were given in Table 9. Also, the findings as to the online game addiction levels of students depending on who introduced the game to players were shown in Figure 3.

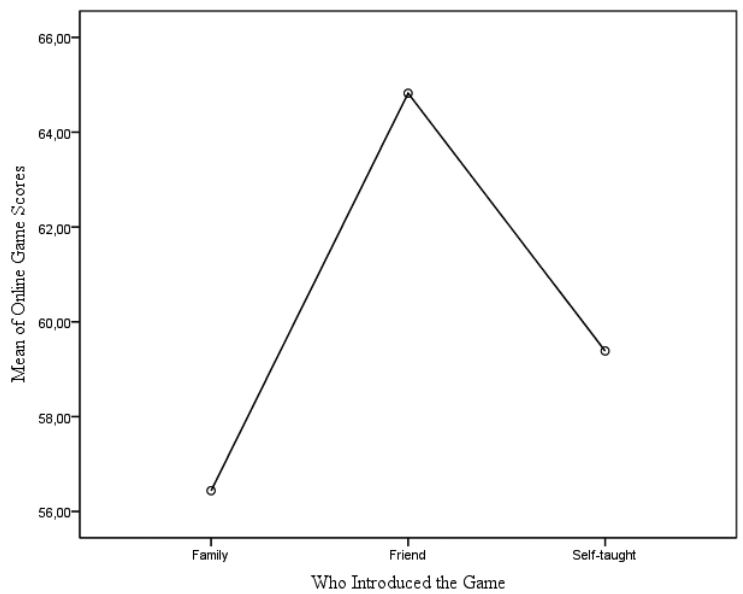

Figure 3. Online Game Addiction Levels of High School Students Depending on Who Introduced Them the Games They Play Lise.

Table 6. Tamhane's T2 Test Results.

\begin{tabular}{llccccc}
\hline & & & & & \multicolumn{2}{c}{$95 \%$ Confidence Interval } \\
\cline { 5 - 7 } (I) Game Type & J) Game Type & Mean Difference (I-J) & Standard Error & $p$ & Lower limit & Upper limit \\
\hline League of Legends & Counter Strike GO & 6.570 & 3.832 & .440 & -3.900 & 17.041 \\
& Facebook Games & $\mathbf{1 4 . 3 7 8 ^ { * }}$ & 2.570 & $\mathbf{. 0 0 0}$ & 7.499 & 21.257 \\
& Other & $\mathbf{9 . 0 1 6 ^ { * }}$ & 2.537 & $\mathbf{. 0 0 3}$ & 2.230 & 15.801 \\
\hline Counter Strike GO & League of Legends & -6.570 & 3.832 & .440 & -17.041 & 3.900 \\
& Facebook Games & 7.808 & 3.700 & .218 & -2.353 & 17.968 \\
& Other & 2.445 & 3.677 & .986 & -7.659 & 12.550 \\
\hline Facebook Games & League of Legends & $\mathbf{- 1 4 . 3 7 8 ^ { * }}$ & 2.570 & $\mathbf{. 0 0 0}$ & -21.257 & -7.499 \\
& Counter Strike GO & -7.808 & 3.700 & .218 & -17.968 & 2.353 \\
& Other & -5.362 & 2.334 & .132 & -11.611 & .886 \\
\hline Other & League of Legends & $\mathbf{- 9 . 0 1 6 ^ { * }}$ & 2.537 & $\mathbf{. 0 0 3}$ & -15.801 & -2.230 \\
& Counter Strike GO & -2.445 & 3.677 & .986 & -12.550 & 7.6594 \\
& Facebook Games & 5.362 & 2.334 & .132 & -.886 & 11.6108 \\
\hline$* p<.05$ & & & & &
\end{tabular}

Table 7. Descriptive Statistics Results.

\begin{tabular}{|c|c|c|c|c|c|c|c|}
\hline \multirow[b]{2}{*}{ Person who introduced the game to player } & \multirow[b]{2}{*}{$N$} & \multirow[b]{2}{*}{$\bar{x}$} & \multirow[b]{2}{*}{ SS } & \multicolumn{2}{|c|}{$95 \%$ Confidence Interval } & \multirow[b]{2}{*}{ Lowest Score } & \multirow[b]{2}{*}{ Highest Score } \\
\hline & & & & Lower Limit & Upper Limit & & \\
\hline Family & 41 & 56.44 & 13.70 & 52.114 & 60.765 & 36.00 & 94.00 \\
\hline Friend & 56 & 64.82 & 14.73 & 60.878 & 68.765 & 35.00 & 93.00 \\
\hline Self-taught & 117 & 59.39 & 16.09 & 56.439 & 62.330 & 27.00 & 97.00 \\
\hline Total & 214 & 60.24 & 15.52 & 58.152 & 62.334 & 27.00 & 97.00 \\
\hline
\end{tabular}


As shown as indicated by the results of one-way analysis of variance given in Tables 7, 8 and 9, online gaming addiction levels varied depending on the person who introduced the game to players. Students that learned the game from their friends re- ceived higher scores $(\overline{\boldsymbol{x}}=64.82)$ than those that learned the game from their families $(\overline{\boldsymbol{x}}=56.44)$, with a statistically significant difference. No significant difference was found for other two pairwise comparisons.

Table 8. One-Way Analysis of Variance Results.

\begin{tabular}{|c|c|c|c|c|c|c|c|}
\hline Levene test & $p$ & Variance Source & Sum of Squares & $\mathrm{df}$ & Mean Square. & $F$ & $p$ \\
\hline \multirow{3}{*}{1.26} & \multirow{3}{*}{.285} & Between Groups & 1853.360 & 2 & 926.680 & & \\
\hline & & Within Groups & 49460.004 & 211 & 234.408 & 3.953 & .021 \\
\hline & & Total & 51313.364 & 213 & & & \\
\hline
\end{tabular}

Table 9. Scheffe's Test Results

\begin{tabular}{|c|c|c|c|c|c|c|}
\hline \multirow[b]{2}{*}{ (I) Who introduced the game } & \multirow[b]{2}{*}{ (J) Who introduced the game } & \multirow[b]{2}{*}{ Mean Difference (I-J) } & \multirow[b]{2}{*}{ Standard Error } & \multirow[b]{2}{*}{$p$} & \multicolumn{2}{|c|}{$\%$ 95Confidence interval } \\
\hline & & & & & Lower limit & Upper limit \\
\hline \multirow[t]{2}{*}{ Family } & Friend & $-8.382^{*}$ & 3.147 & .031 & -16.1403 & -.6245 \\
\hline & Self-taught & -2.946 & 2.779 & .571 & -9.7955 & 3.9043 \\
\hline \multirow[t]{2}{*}{ Friend } & Family & $8.382^{*}$ & 3.147 & .031 & .6245 & 16.1403 \\
\hline & Self-taught & 5.437 & 2.488 & .094 & -.6963 & 11.5699 \\
\hline \multirow[t]{2}{*}{ Self-taught } & Family & 2.946 & 2.779 & .571 & -3.9043 & 9.7955 \\
\hline & Self-taught & -5.437 & 2.488 & .094 & -11.5699 & .6963 \\
\hline
\end{tabular}

${ }^{*}=p<.05$

\section{Discussion}

The research was carried out to determine the relationship between online game addiction of high school students and their psychological needs and sensation seeking behaviors. The results show that there is a positive correlation between sensation seeking behaviors and online game addiction, which is consistent with previous research results (Mehroof \& Griffiths, 2010). Reportedly, risk-taking and sensation seeking behaviors increase in adolescence period (Chambers, Taylor, \& Potenza, 2003). Sensation seeking tendencies of adolescents may direct them towards online games as a result of isolation from the physical world.

With their neverending evolution, games take part in every stage of our lives as important tools that fulfill individuals' need for fun and adventure. For instance, as a result of technological developments, video games widely played by teenagers before 2000s are now replaced by computer games. Also, increasing number of online games are released in line with rapidly developing computer and internet technologies. Such online games have even taken place in the Guinness Book of World Records.

Since having success in online games is a matter of seconds, such games become attractive for adolescents as a means for fulfilling their need for adventure and fun. Rapidly-developing world of information technologies have allowed teenagers to gain more access to online games (e.g. via smart phones, tablets, computers, wifi-tvs, etc), thus withholding them from fulfilling their sensation seeking behaviors with various social activities, and such tendencies may result with addictive behaviors such as online game addiction. In this regard, this study may be useful for detecting the correlation between sensation seeking and online game addiction.
Findings of the research show that, psychological needs can be considered another predictor for online gaming tendencies. In the related literature no study on the relationship between psychological needs and online games was found. As Granic, Lobel, and Engels, (2014) stated that playin video games have positive effect in terms of cognitive, motivational, emotional, and social. In this context the following conclusion can be reached. In general, online games can be regarded as a means for fulfillment of psychological needs. As in the case of the need for success among psycholocial needs, online games are based upon the feeling of success, which may provide the invididual with enjoyment followed by fulfillment of this feeling. In other words, the need for success may predict online game addiction, as individuals may fulfill their need for success via games. Likewise, adolescents are considered to fulfill their need for relatedness partially with games, since online games involve millions of people which provide players with the opportunity to choose and prefer another individual to fulfill their needs. Additionally in some of the games the use of microphone is also enabled in addition to typing, and individuals can fulfill their need for relatedness by communicating with other people.

Online game addicts may tend to such games as a result of their nonfulfilled need for relatedness in their daily lives. Given the fact that communication with other people is based upon gaining recognition of others and recognizing them. As argued by some researchers (e.g. Granic, Lobel, and Engels, 2014; Gray, 2012; Vitelli, 2014; Olson, 2010), the activity of playing online games may provide such people with the opportunity to communicate more easily, as such activities only reveal the game-playing behaviors and personality of individuals. In a survey which is in furtherance of this argument and conducted by Lo, Wang and Frang (2005) stu- 
dents who play online games were contextualized in three groups. These are students who play online games in an obsessional way, students who play occasionally and those who never play. When considering students' social anxiety, it can be seen that students those who play online games in an obsessional way is the highest group.

Accordingly, individuals that fail to fulfill their need for relatedness in their daily lives may tend to play online games at higher rates. In other words, online gaming trends among adolescents can be attributed to nonfulfillment of their psychological needs. It is a known fact that an average adolescent has the means to fulfill his/her needs for success, relatedness and autonomy in his/her social life as well. However, they can be misdirected when their parents fail to provide them with a proper environment or in the presence of some changes resulting from a critical stage of their lives such as adolescence (individual's undergoing issues with his/her environment, family's attitude, adolescence-related neuroticism, physical development, adaptation problems) and they may develop tendencies such as playing online games to fulfill their needs.

When the surveys about online games are examined, it can be seen that the internet and computer usage is an essential variable. (Lo, wang and Frang, 2005 Van Rooij, Schoenmakers, Vermulst, Van Deb Eijnden, Van De Mheen, 2011). An adult is more likely to have the awareness for functional use of online games, whereas high school students may unwittingly tend to play such games to fulfill their psychological needs which are not met in the presence of their families or in their daily social lives. Moreover, such games have become a profession among players under the name of E-sports; and reportedly a tournament organized in 2016 granted a total of 20.770.460 USD reward. Given such amounts, adolescents' tendency towards such games becomes even more likely, since acquisition of physical rewards can fulfill the psychological needs of adolescents although partially. Also, some universities in Turkey grant scholarships reaching up to 40.000 TL to students that gain high

\section{References}

Albert, D., \& Steinberg, L. (2011). Judgment and decision making in adolescence. Journal of Research on Adolescence, 21(1), 211-224.

Arslanoğlu, E., Tekin, M., Arslanoğlu, C., \& Özmutlu, İ. (2010). Voleybol hakemlerinin çeşitli değişkenlere göre kaygı ve temel psikolojik ihtiyaç düzeylerinin incelenmesi. Uluslararası Insan Bilimleri Dergisi, 7(2), 985-995.

Bahçeşehir Üniversitesi, İstanbul, Haberler. (2017, Mart). Bahçesebir Üniversitesi'nden Türkiye'de bir ilk: ESPOR bursu. Erişim tarihi: 10, 03, 2017, http://www.bahcesehir.edu.tr/icerik/11765-bahcesehir-universitesindenturkiyede-bir-ilk-espor-bursu.

Balci, Ş., \& Ayhan, B. (2007). Üniversite öğrencilerinin internet kullanım ve doyumları üzerine bir saha araştırması. Selçuk. Üniversitesi İletişim Fakültesi Akademik. Dergisi, 5(1), 174-197.

Blaszczynski, A. P., Wilson, A. C., \& McConaghy, N. (1986). Sensation seeking and pathological gambling. Addiction, 81(1), 113-117.

Carton, S., Jouvent, R., Bungener, C., \& Widlöcher, D. (1992). Sensation seeking and depressive mood. Personality and Individual Differences, 13(7), 843-849.

Canoğulları, Ö. (2014). Internet bağımlllk düzeyleri farkll ergenlerin cinsiyetlerine göre psikolojik ibtiyaçlar, sosyal kaygular ve anne baba tutum algzlarmin incelenmesi (Yayınlanmamış yüksek lisans tezi). Çukurova Üniversitesi, Adana. ranks in some of the online games (Bahçeşehir University, 2017). In some countries such as China, universities are established for online gaming to train players. In other words, an individual trained for playing online games gets in competitions, gets paid per competition and attends tournaments like a football player. Also, it is known that customized facilities are established for these purposes. In total, these may render online gaming much more appealing for students.

It should not be overlooked that, such online games released on the internet for use of millions of people may be both advantageous and dangerous for adolescents. Adolescents may choose to play online games for professional purposes instead of considering them a resort for fulfilling their needs, provided that adults and authorized individuals in the society raise awareness for functional use of such games.

In light of the results of this study, individuals can be taught how to fulfill their psychological needs in their social environment by use of a psycho-training program for adolescents in future studies. After these sessions, it could be checked whether online game addictions of individuals are reduced. Schemas can be prepared for online game addiction levels and relationship with these schemas can be investigated. A similar study can be conducted on middle school students to pave the way for preventive works. Finally, personality types and online game addiction can be collectively studied to determine which of the personality types are exposed to risk of gaming addiction.

\section{Limitations}

In spite of obtaining essential findings about variences of adolescents' online game addcition, there are still some limitaitons which are; to have a working group which is limited to 214 students, not to be able to land up with casual results because of correlational survey model, the data are just obtained from an assessment instrument based on self-report and the working group was restricted with adolescent's sample.

Casey, B. J., Duhoux, S., \& Cohen, M. M. (2010). Adolescence: What do transmission, transition, and translation have to do with it? Neuron, 67(5), 749760.

Chambers, R. A., Taylor, J. R. \& Potenza, M. N. (2003). Developmental neurocircuitry of motivation in adolescence: a critical period of addiction vulnerability. The AmericanJournal of Psycbiatry, 160(6), 1041-1052.

Chein, J., Albert, D., O'Brien, L., Uckert, K., \& Steinberg, L. (2011). Peers increase adolescent risk taking by enhancing activity in the brain' sreward circuitry. Developmental Science, 14(2), F1-F10.

Chiu, S. I., Lee, J. Z., \& Huang, D. H. (2004). Video game addiction in children and teenagers in Taiwan. Cyber Psychology \& behavior, 7(5), 571-581.

Christensen, L. B., Johnson, R. B., \& Turner, L. A., (2015). Araștrma yöntemleri, desen ve analiz (Çev. Ed. Ahmet Aypay). Anı Yayıncılık, Ankara.

Coventry, K. R., \& Brown, R. (1993). Sensation seeking, gambling and gambling addictions. Addiction, 88(4), 541-554.

Cross, C. P., Cyrenne, D. L. M., \& Brown, G. R. (2013). Sex differences in sensation-seeking: a meta-analysis. Scientific reports, 3, 2486. Doi: $10.1038 /$ srep02486 
Çelik, E. (2015). Kendini Gizleme ve Yaşam Doyumu Arasındaki İlişkide Heyecan Arayıșının Aracilık ve Moderatör Rolü. Eğitim Ve Bilim, 40(181).

Çetin, A. B., \& Ceyhan, A. A. (2014). Ergenlerin internette kimlik denemeleri ve problemli internet kullanım davranıslar1. Addicta: The Turkish Journal on Addictions., 1(2), 5-46.

Deci, E. L, \& Ryan, R. M. (2000). The 'what' and 'why' of goal pursuits: Human needs and the self-determination of behavior. Psychological Inquiry, 11(4), 227 268.

Dilmaç, B. (2009). Sanal zorbalığ1 yordayan psikolojik ihtiyaçlar: Lisans öğrencileri için bir ön çalıșma. Educational Sciences: Theory \& Practice, 9(3), 1291-1325.

Kesici, S., Üre, Ö., Bozgeyikli, H. ve Sünbül, A. M. (9-11 Temmuz 2003). Temel psikolojike ibtivaclar ölceğinin gecerlilik ve güvenirliği. VII. Ulusal Psikolojik Damısmo ve Rehberlik Kongresi, Malatya.Ersche, K. D., Turton, A. J., Pradhan, S., Bullmore, E. T., \& Robbins, T. W. (2010). Drug addiction endophenotypes: impulsive versus sensation seeking personality traits. Biologicalpsychiatry, 68(8), 770-773.

Farrell, J. M., Reiss, N., \& Shaw, I. A. (2014). Sema terapi klinisyenin rehberi (Çev. S. G. Alkan ve E. Alkan. Psikonet Yayınları, istanbul.

Gray, P. (2012, January 7). The many benefits, for kids, of playing video games. Retrieved from https://www.psychologytoday.com/us/blog/freedomlearn/201201/the-many-benefits-kids-plaving-video-games

Granic, I., Lobel, A., \& Engels, R. C. M. E. (2014). The benefits of playing video games. American Psychologist, 69(1), 66-78. http://dx.doi.org/10.1037/a0034857

Hamurcu, H., \& Sargın, N. (2011). Lise öğrencilerinin boyun eğme davranışları ile psikolojik ihtiyaçları arasındaki iliş̧kinin incelenmesi. Erciyes Üniversitesi Sosyal Bilimler Enstitïsü Dergisi, 31(1), 171-187.

Kosten, T. A., Ball, S. A., \& Rounsaville, B. J. (1994). A sibling study of sensation seeking and opiate addiction. The Journal of nervous and mental disease, 182(5), 284-289.

Kaya, A. B., (2013). Cevrimiçi oyun bağzmllhğ ölçeğinin gelişstirilmesi: Geçerlik ve güvenirlike çalışması (Yayınlanmamış Yüksek Lisans Tezi). Gaziosmanpaşa Üniversitesi, Tokat.

Karaman, N. G. (2013). Ergenlerde risk almanın içsel kaynaklarının benmerkezlilik, akran baskısı, sosyo-ekonomik düzey ve cinsiyet açısından incelenmesi. İlk.̈̈gretim Online, 12(2).

Kaygusuz, C. (2013). Psikolojik ihtiyaçlar ve internet bağımlilığı. Ankara: An Yaymolik.

Kelley, A. E., Schochet, T., \& Landry, C. F. (2004). Risk taking and novelty seeking in adolescence: Introduction to part I. Annals of the New York Academy of Sciences, 1021(1), 27-32.

Kesici, Ş. (2008). Yeni psikolojik ihtiyaç değerlendirme ölçeğinin Türkçe formunun gecerlik vegüvenirlik çalışması: doğrulayıcı faktör analizi sonuçları. Selçuk Üniversitesi Sosyal Bilimler Enstitüsü Dergisi, 20, 493-500.

Kuzgun, Y. (1988). Edwards Kişisel Tercih Envanterinin Türkiye'de geçerlik ve 85 güvenirliliği. Ankara Üniversitesi Eğitim Bilimleri Fakültesi Dergisi, 1(17),

Kim, E. J., Namkoong, K., Ku, T., \& Kim, S. J. (2008). The relationship between online game addiction and aggression, self control and narcissistic personality traits. European psychiatry, 23(3), 212-218.

Ko, C. H., Yen, J. Y., Chen, C. C., Chen, S. H., \& Yen, C. F. (2005). Gender differences and related factors affecting online gaming addiction among Taiwanese adolescents. The Journal of Nervous and Mental Disease, 193(4), 273277.

Lemmens, J. S., Valkenburg, P. M., \& Peter, J. (2009). Development and validation of a game addiction scale for adolescents. Media Psychology, 12(1), 77-95.

Lin, S. S., \& Tsai, C. C. (2002). Sensation seeking and internet dependence of Taiwanese high school adolescents. Computers in Human Behavior, 18(4), 411426.
Madran, D., \& Çakılcı, F. (2014). Çok oyunculu çevrimiçi video oyunu oynayan bireylerde video oyunu bağımlılığı ve saldırganlık. Anadolu Psikiyatri Dergisi, 15, 99-107.

McInroy, L. B., \& Mishna, F. (2017). Cyberbullying on Online Gaming Platforms for Children and Youth. Child and Adolescent Social Work Journal, 34(6), 597-607.

Mehroof, M., \& Griffiths, M. D. (2010). Online gaming addiction: The role of sensation seeking, self-control, neuroticism, aggression, state anxiety, and trait anxiety. Cyberpsychology, Behavior, and Social Networking, 13(3), 313-316.

Olson, C. K. (2010). Children's motivations for video game play in the context of normal development. Review of General Psychology, 14(2), 180-187. Doi: $10.1037 / \mathrm{a} 0018984$

Rahmani, S., \& Lavasani, M. G. (2011). The comparison of sensation seeking andfivebigfactors of personality between internet dependents and nondependents. Procedia-Social and Behavioral Sciences, 15, 1029-1033.

Rahmani, S., \& Lavasani, M. G. (2011). The relationship between internet dependency with sensation seeking and personality. Procedia-Social and Behavior al Sciences, 30, 272-277.

Rahmani, S., \& Lavasani, M. G. (2012). Gender differences in five factor model of personality and sensation seeking. Procedia-Social and Behavioral Sciences, 46, 2906-2911.

Rolison, M. R., \& Scherman, A. (2003). College student risk taking from three perspectives. Adolescence, $38(152), 689$.

Peltoniemi, T. (2002, March). Net addiction in Finland. In First prevent conference of telematics in addiction prevention, Athens, Greece.

Steinberg, L. (2007). Ergenlik. (Cev. Figen Cok vd.). Ankara: İmge Kitabevi.

Stephenson, M. T., \& Southwell, B. G. (2006). Sensation seeking, the activation model, and mass media health campaigns: Current findings and future directions for cancer communication. Journal of Communication, 56(1), S38-S56.

Swatman, R. (2016). Chinese Dota 2 Gaming team wins largest prize for an e Sports competitionever. Erişim tarihi: 14, 07, 2017, http://www.guinnessworldrecords.com/news/brand-oragency/2016/10/chinese-gaming-team-wins-largest-prize-for-an-esportscompetition-ever-448932

TÜiK (2013) 06-15 yaş grubu çocuklarda bilişim teknolojileri kullanımı ve medya. Erișim $\quad$ Tarihi: bttp:/ / wnw.tuik.gov.tr/PreHaberBultenleri.do?id $=15866$

Van Rooij, A. J., Schoenmakers, T. M., Van de Eijnden, R. J., \& Van de Mheen, D. (2010). Compulsive internet use: the role of online gaming and other internet applications. Journal of Adolescent Health, 47(1), 51-57.

Vitelli, R. (2014, February 10). Are there benefits in playing video games? Retrieved from https://www.psychologytoday.com/us/blog/mediaspotlight/201402/are-there-benefits-in-plaving-video-games

Yarkın, E. (2013). Temel psikolojile ibtiyaçlarn karşılanma düzeyinin ilişki doyum ve yaşam doyum düzeyine katkıısını incelenmesi (Yayınlanmamış Yüksek lisans tezi). İstanbul Arel Üniversitesi, Sosval Bilimler Enstitüsü

Yiğit, R. (2012). Konya ilinde öğrenim gören yabanc1 uyruklu üniversite öğrencilerinin temel psikolojik ihtiyaçlarının bir kısım değişkenler bakımından incelenmesi. Selçuk Üniversitesi Sosyal Bilimler Enstitüsü Dergisi, (27), 317-326.

Yilmaz, E., \& Cağıltay, K. (2005). History of digitalgames in Turkey. Proceedings of DIGRA 2005 Conference: ChangingViews-Worlds in Play.

Kimberly Young (2009) Understanding online gaming addiction and treatment issues for adolescents. The American Journal of Family Therapy, 37(5), 355-372. DOI: $10.1080 / 01926180902942191$

Young, K. S. (1998). Internet addiction: The emergence of a new clinical disorder. Cyberpsychology \& Behavior, 1(3), 237-244. 